\title{
Penilaian Makro Arsip: Dasar Hukum, Metode dan Implementasinya
}

\author{
${ }^{1}$ Ursa Agniya, ${ }^{2}$ Nina Mayesti \\ 1,2 Universitas Indonesia
}

\section{ABSTRACT}

An appraisal is one of the main activities in the archive management system. Although it is not directly explained, the appraisal of archives in Indonesia is carried out to carry out archive depreciation activities. Therefore in appraising archives, it must be guided by the applicable laws. Archive macro-appraisal is a top-down appraisal where archivists or archive managers no longer assess archives as an end of the organizational process or bottom-up. A macro appraisal is an approach to archive valuation. It discusses appraisal techniques and macro-appraisal at a theoretical level whose main objective is not theoretical discourse but rather a methodological exploration. Many archivists apply the macro-appraisal methodology but mostly make modifications in the actual application. A small proportion of public archive archivists have consciously and successfully applied this approach theoretically consistent. Regardless of the results to date, the nature of macro appraisal implementation raises whether macro appraisal theory is a factual basis for standardization.

\section{INTISARI}

Penilaian arsip merupakan salah satu kegiatan utama dalam sistem pengelolaan arsip. Meski tidak dijelaskan secara langsung, penilaian arsip di Indonesia dilakukan dalam rangka melakukan kegiatan penyusutan arsip, maka dari itu dalam melakukan penilaian arsip haruslah berpedoman pada undang-undangan yang berlaku. Penilaian makro arsip merupakan penilaian yang bersifat top-down dimana arsiparis atau pengelola arsip tidak lagi menilai arsip sebagai sebuah akhir dari proses kegiatan organisasi atau bottom-up. Penilaian makro merupakan sebuah pendekatan untuk penilaian arsip dan membahas mengenai teknik penilaian dan penilaian makro pada tingkat teoritis yang tujuan utamanya bukan wacana teoritis tetapi lebih ke eksplorasi metodologi. Dalam implementasinya, arsiparis banyak yang menerapkan metodologi penilaian makro namun kebanyakan melakukan modifikasi dalam penerapan yang sebenarnya. Singkatnya, sebagian kecil arsiparis arsip publik telah secara sadar dan berhasil menerapkan pendekatan ini secara teoritis konsisten. Terlepas dari hasil untuk saat ini, karakter implementasi penilaian makro menimbulkan pertanyaan apakah teori penilaian makro dengan sendirinya merupakan dasar yang kuat untuk standardisasi. Penelitian ini adalah tinjauan literatur dimana akan mengeksplorasi mengenai dasar hukum dalam penilaian makro arsip yang di terapkan di Indonesia, serta memberi pengetahuan mengenai metode dalam melakukan penilaian dan contoh implementasi dari penerapan penilaian makro arsip yang telah dilakukan dalam organisasi.
Submitted: $2 / 12 / 2020$

Received: 28/12/2020

*Correspondence: Ursa Agniya

ursaagniya@gmail.com

KEYWORDS: appraisal

Archives MacroAppraisal

archival legal basis

literature review

KATA KUNCl: penilaian

Penilaian Makro Arsip

dasar hukum kearsipan

tinjauan literatur

CITE THIS ARTICLE:

Agniya, U., Mayesti, N. (2020). Penilaian Makro Arsip: Dasar Hukum, Metode dan Implementasinya. . Jurnal Diplomatika, 4 (1), 49-56. 


\section{PENDAHULUAN}

Arsip merupakan salah satu bagian penting dari sumber informasi penting bagi seorang individu maupun bagi sebuah organisasi. Keberadaan arsip bagi suatu organisasi tidak hanya menjadi bukti sejarah, tetapi memiliki fungsi dan nilai guna yang beragam. Secara fungsional, suatu arsip akan dibutuhkan oleh pimpinan sebagai bahan pertimbangan dalam pengambilan keputusan organisasi. Arsip juga dibutuhkan sebagai bahan acauan dalam perencanaan organisasi. (Sasmita \& Sutirman, 2017).

Arsip didefinisikan pada Undang-undang No. 43 tahun 2009 sebagai rekaman peristiwa atau kegiatan yang diterima oleh lembaga negara, pemerintah daerah, perusahaan, organisasi politik, lembaga pendidikan, dan perseorangan untuk pelaksanaan kehidupan bermasyarakat yang berupa berbagai bentuk dan media sosial dengan perkembangan komunikasi dan perkembangan teknologi informasi. Dalam ISO 15489-1 (Records Management - Part 1: General), arsip adalah informasi yang diciptakan, diterima dan disimpan sebagai bukti dan informasi oleh suatu organisasi atau seseorang, dalam rangka memenuhi kewajiban hukumnya atau dalam rangka transaksi bisnis. Sementara dalam Electronic Records: A Workbook for Archivists maupun dalam Guide for Managing Electronic Records from an Archival Perspective, arsip didefinisikan sebagai informasi terekam (rekaman informasi) yang dibuat atau diterima dalam proses memulai, melaksanakan dan menyelesaikan aktivitas institusi atau perorangan dan mengandung konten, konteks dan struktur yang memadai untuk menjadi bukti dari aktivitas tersebut (International Council on Archives, 1997)

Effendhie menjelaskan bahwa arsip secara tradisional dianggap sebagai repositori netral dan objektif untuk merekam secara autentik aktivitas manusia. Lebih lanjut, Effendhie juga mengungkap bahwa sebagian besar arsip diciptakan bersamaan dengan kejadian yang mereka catat, dokumen dan arsip dianggap sebagai saksi yang tidak memihak pada peristiwa sejarah. (Effendhie, 2019). Schwartz dan Cook dalam tulisannya menyatakan bahwa Arsip adalah konstruksi sosial. Asal-usul arsip terletak pada kebutuhan informasi dan nilai-nilai sosial para penguasa, pemerintah, bisnis, asosiasi, dan individu yang membangun dan memelihara Arsip. Meskipun ada perubahan dalam sifat arsip, kegunaan untuk arsip itu, dan kebutuhan untuk melestarikannya. (Schwartz \& Cook, 2002).

Melihat kepentingan tersebut perlu dilakukan pengelolaan arsip secara baik dan benar dimana arsip tersebut berarti harus ditata secara sistematis sehingga jika kelak di masa depan arsip tersebut dibutuhkan dapat dengan cepat, tepat dan lengkap di berikan. Dalam sistem pengelolaan arsip, proses appraisal atau proses penilaian merupakan salah satu kegiatan utama dalam sistem pengelolaan arsip. Dalam Peraturan Pemerintah Nomor 87 Tahun 1999 sendiri disebutkan bahwa bahwa penilaian arsip adalah kegiatan yang menentukan nilai guna dokumen perusahaan berdasarkan pada kegunaan bagi kepentingan pengguna dokumen. Penilaian arsip bertujuan untuk menciptakan nilai dalam arsip dimana dalam penilaian tersebut terkandung teori, alasan, kebijakan, dan prosedur untuk pemilihan nilai arsip (Duranti \& Franks, 2015). Secara historis konsepsi penilaian arsip sudah banyak didiskusikan, metode penilaian arsip banyak dikemukakan oleh praktisi arsiparis salah satu yang paling terkenal yaitu metode penilaian makro (macro appraisal) atau penilaian modern yang dikemukakan oleh Terry Cook dan maka dari itu tulisan dibuat karena akan memaparkan lebih jauh mengeni penilaian arsip modern atau macro appraisal serta contoh praktik dalam penerapan metode tersebut. Hal ini disebabkan karena penelitian mengenai penilaian arsip masih sangat jarang dilakukan akibat kurangnya pengetahuan mengenai penilaian arsip dan demikian rumusan masalah dalam penelitian ini yaitu: 
1. Apa saja dasar hukum dalam melakukan penilaian arsip? Khususnya dalam ruang lingkup instansi pemerintah?

2. Bagaimana metode dalam melakukan penilaian makro arsip?

3. Bagaimana implementasi penilaian makro arsip dalam lingkup organisasi?

\section{METODE PENELITIAN}

Penelitian ini adalah penelitian kepustakaan atau penelitian literatur review dimana menurut Embun dalam Melfianora penelitian kepustakaan adalah penelitian yang dilakukan berdasarkan karya tertulis, termasuk hasil penelitian yang telah maupun yang belum dipublikasikan. Lebih lanjut dijelaskan bahwa penelitian literatur review tidak diharuskan untuk terjun langung kelapangan dan bertemu dengan responden, data-data yang dibutuhkan dalam penelitian literatur review dapat diperolah dari sumber-sumber pustaka maupun dokumen pendukung lainnya (Melfianora, 2019). Penelitian ini menghimpun data dari undang-undang, peraturan kepala ANRI serta Surat Edaran sebagai landasan penetapan dasar hukum penilaian arsip. Artikel-artikel dalam jurnal dalam negeri dan internasional mengenai Macro Appraisal di himpun, dikumpulkan dan dianalisis untuk mengetahui konsep dan metode penilaian makro arsip, serta melakukan pencarian penelitian terdahulu mengenai kajian penerapan macro-appraisal dalam organisasi untuk mengetahui implementasi penilaian makro arsip dalam organisasi.

\section{HASIL DAN PEMBAHASAN}

\section{Dasar Hukum Penilaian Arsip di Indonesia}

Di Indonesia, dasar hukum merupakan sebuah pedoman dalam melakukan penilaian arsip. Meski tidak dijelaskan secara langsung, penilaian arsip di Indonesia dilakukan dalam rangka melakukan kegiatan penyusutan arsip, maka dari itu dalam melakukan penilaian arsip haruslah berpedoman pada undang-undangan yang berlaku. Adapun dasar hukum mengenai penilaian arsip khususnya pada instansi pemerintah diantaranya:

1. Undang - Undang No. 43 Tahun 2009 tentang Kearsipan.

Undang-undang ini tidak menjelaskan secara langsung mengenai penilaian arsip, namun dalam pasal 2 dijelaskan mengenai arsip statis dimana dalam memutuskan status arsip statis ini tentunya terdapat kegiatan penilaian arsip.

2. Peraturan Kepala ANRI (PERKA ANRI) No. 37 Tahun 2016 tentang Pedoman Penyusutan Kearsipan.

Perka ini menjelaskan mengenai Pedoman Penyusutan Arsip dimana dalam pedoman tersebut dijelaskan bahwa penyusutan arsip adalah kegiatan pengurangan jumlah arsip dengan cara pemindahan Arsip Inaktif dari unit pengolah ke unit kearsipan, pemusnahan arsip yang tidak memiliki nilai guna, dan penyerahan arsip statis kepada lembaga kearsipan. Dari kegiatan penyusutan arsip ini tentunya terjadi penilaian arsip yaitu penilaian dalam pemindahan arsip Inaktif dari unit pengolah ke unit kearsipan, pemusnahan arsip yang tidak memiliki nilai guna, dan penyerahan arsip statis

3. Peraturan Kepala ANRI (PERKA ANRI) No. 47 Tahun 2015 tentang Jadwal Retensi Arsip

Perka ini menjelaskan mengenai Jadwal Retensi Arsip (JRA) dimana JRA diartikan sebagai daftar yang berisi sekurang-kurangnya jangka waktu penyimpanan atau retensi, jenis arsip, dan keterangan yang berisi rekomendasi tentang penetapan suatu jenis arsip yang dimusnahkan, dinilai kembali, atau dipermanenkan yang dipergunakan sebagai pedoman penyusutan dan penyelamatan arsip. Dalam pengertian JRA ini jelas disebutkan mengenai penilaian kembali sebuah arsip 
yang berarti sebuah arsib sebelumnya sudah dilakukan penilaian.

4. Peraturan Pemerintah No. 34 tahun 1979 tentang Penyusutan Arsip

Peraturan Pemerintah ini menjelaskan kegiatan dan proses penyusutan yang terdiri dari kegiatan pemindahan, pemusnahan dan penyerahan. Dari proses dan kegiatan ini juga secara tidak langsung diketahui bahwa terjadi penilaian arsip yakni pada saat melakukan kegiatan pemindahan, pemusnahan dan penyerahan arsip.

5. Surat Edaran Kepala ANRI Indonesia Nomor: SE/02/1983 Tanggal 16 Mei 1983 tentang Pedoman Umum untuk Menentukan Nilai Guna Arsip.

Surat edaran ini menjelaskan mengenai penentuan nilai guna arsip dalam rangka pelaksanaan kegiatan penyusutan serta kegiatan penyusutan yang dilaksanakan dalam tata kearsipan. Penentuan nilai guna arsip terbagi menjadi dua kategori; kategori pertama yaitu arsip yang bernilai guna permanen sehingga harus terus disimpan dan kategori kedua yaitu arsip yang bernilai guna sementara dimana arsip dalam kategori ini dapat dimusnahkan dengan segera maupun dimusnahkan dikemudian hari. Nilai guna arsip sendiri dapat berubah sesuai fungsi dan kegunaannya. Penilaian arsip tidak dapat dilakukan secara individu, namun diperlukan nalar dan keahlian dari orang yang ahli yang menilai berbagai kegunaan arsip, isi arsip dan fungsi arsip

Dalam lingkungan BUMN sendiri dasar hukum mengenai penilaian arsip mengacu pada Undang-Undang No. 8 Tahun 1997 tentang Dokumen Perusahaan dimana dalam pasal 3 dijelaskan mengenai Jadwal Retensi sebagai jangka waktu penyimpanan dokumen perusahaan yang disusun dalam suatu daftar sesuai dengan jenis dan nilai kegunaannya dan dipakai sebagai pedoman pemusnahan dokumen perusahaan dan Peraturan Pemerintah No. 87 Tahun 1997 tentang Tata Cara Penyerahan dan Pemusnahan Dokumen Perusahaan.

\section{Metode Penilaian Arsip Makro}

Terry Cook menjelaskan bahwa penilaian macro merupakan penilaian yang bersifat top -down dimana arsiparis atau pengelola arsip tidak lagi menilai arsip sebagai sebuah akhir dari proses kegiatan organisasi atau bottom-up. Penilaian top-down dalam penilaian arsip sudah ditentukan sejak awal sebuah arsip diciptakan. Lebih lanjut Terry Cook juga berpendapat bahwa penilaian makro cocok digunakan dalam tingkat pemerintahan, universitas, dan perusahaan bisnis lainnya. Penilaian macro juga dikenal sebagai Canadian way dalam melakukan penilaian karena penilaian makro terkenal sejak penilaian makro dikonseptualisasikan dan diluncurkan di Pemerintah Kanada lebih dari satu dekade yang lalu, penilaian ini telah berkembang dengan cara yang terencana dan tidak terencana dan timbul pujian, kritik, peniruan, dan adaptasi internasional (Cook, 2005).

Beaven kemudian dalam tulisannya menyebutkan bahwa teori penilaian makro menggeser fokus penilaian dari produk penciptaan arsip ke konteks proses penciptaan arsip. Lebih lanjut Beaven juga menjelaskan bahwa penilian makro berfokus pada proses pencipta arsip berbeda dengan penilaian mikro atau penilaian tradisional yang berorientasi pada produk arsip. Beaven juga menjelaskan bahwa penilaian makro pada awalnya dimulai sebagai strategi akuisisi dimana awalnya akan mengevaluasi cakupan keseluruhan, konten, sifat, dan pentingnya seluruh jajaran organisasi dan fungsi. Penilaian mikro dirancang untuk memvalidasi dan menyempurnakan hipotesis yang ditetapkan sebelumnya tentang lokasi aktivitas fungsional terpenting organisasi dan pencipta arsip (Beaven, 1999)

Dalam melakukan penilaian makro, Beaven menjelaskan bahwa terdapat tiga keuntungan dalam pelaksanaan penilaian makro; Pertama penilaian makro 
membebaskan arsiparis dari bahaya atas asumsi tentang nilai sebuah arsip yang dapat mengganggu saat menyusun strategi akuisisi atau penilaian. Kedua, penilaian makro menghilangkan risiko prasangka yang tidak semestinya terkait penggunaan atau pengguna arsip di masa mendatang dan yang terakhir, penilaian makro menggeser penilaian dari fokus pasif pada arsip apa pun yang terjadi menjadi fokus terencana. (Beaven, 1999)

Cook sendiri mengemukakan bahwa setidaknya terdapat 10 kunci utama dari penilaian makro yaitu (Cook, 2004)

1. Penilaian makro harus merupakan proses yang aktif dan terencana untuk mengidentifikasi arsip yang memiliki nilai arsip, bukan reaksi pasif terhadap permintaan dari manajer arsip untuk kewenangan menghancurkan arsip.

2. Arsip yang dinilai harus diidentifikasi secara langsung oleh pengarsip berdasarkan kriteria nilai arsip yang telah diartikulasikan sebelumnya

3. Hal terakhir yang harus dilakukan seorang arsiparis dalam menilai adalah mempertimbangkan potensi penggunaan arsip oleh peneliti.

4. Mengingat volume dan kompleksitas arsip modern yang tercipta setiap hari, semua arsip dinilai secara komprehensif pada satu waktu

5. Penilaian makro membutuhkan penelitian ekstensif oleh arsiparis ke dalam budaya organisasi dan fungsi kelembagaan, ke dalam sistem pengarsip, arus informasi, media perekaman, dan perubahan. Jika penilaian berkaitan dengan menentukan nilai jangka panjang untuk arsip, penilaian makro memberikan nilai pada konteks fungsional-struktural dan budaya kerja di mana arsip dibuat dan digunakan oleh penciptanya, dan bagaimana masyarakat berinteraksi dengan konteks dan budaya itu, dan dipengaruhi olehnya.

6. Penilaian adalah proses penentuan nilai yang memutuskan apakah arsip harus disimpan dalam jangka panjang atau dimusnahkan; tidak boleh disamakan dengan akuisisi, yang merupakan proses terpisah (dengan variabel terpisah) yang menentukan apakah arsip yang telah dinilai sebagai arsip benar-benar dapat ditransfer atau disimpan.

7. Tanpa teori atau konsep yang diartikulasikan dengan baik untuk menetapkan nilai penilaian, strategi atau metodologi penilaian apa pun tidak akan pernah diterapkan secara konsisten atau hasilnya dapat dipertahankan ke publik yang semakin waspada dan kritis

8. Teori penilaian tidak memiliki hubungan langsung dengan teori kearsipan. Teori penilaian berkaitan dengan nilai arsip sementara teori arsip berkaitan dengan karakteristik arsip sebagai bukti yang dapat dipercaya. Tentu saja, arsip yang tidak memiliki 'nilai' reliabilitas jarang dinilai memiliki nilai 'appraisal', tapi itu hanya menimbulkan pertanyaan manakah dari milyaran arsip yang benar-benar menunjukkan nilai arsip yang dapat diandalkan yang juga memiliki nilai penilaian.

9. Penilaian merupakan proses subjektif, dan setiap 'nilai' yang menjiwainya akan berbeda dengan waktu, tempat, struktur / posisi pemerintahan, dan budaya masyarakat.

10. Karena kompleksitas penilaian, kepentingan sosial dan subjektivitasnya, arsiparis dan lembaga harus bertanggung jawab atas keputusan mereka melalui dokumentasi penuh dan transparan dari penelitian kontekstual mereka, proses penilaian, keputusan simpan-pemusnahan, dan transfer arsip yang dihasilkan, dan harus membuat dan menerapkan standar tolok ukur yang dengannya proses penilaian itu sendiri dapat dinilai. 
Telah dijelaskan diatas bahwasannya ketika sebuah arsip memiliki value atau nilai, maka timbulah pertanyaan kepada siapa arsip itu bernilai? menggunakan kriteria apa agar arsip tersebut bernilai? dan mengapa arsip tersebut bernilai? Strategi dan metodologi penilaian adalah cara di mana definisi teoretis atau filosofis dari nilai dapat diidentifikasi dan diterapkan dalam realitas kerja. Selanjutnya Cook (2004) menjelaskan lima langkah inti dalam metodologi penilaian makro:

1. Metode penilaian makro menentukan kompleksitas dan kepentingan relatif dari berbagai subfungsi, program dan kegiatan dalam sasaran fungsional yang komprehensif yang menjadi objek proyek penilaian makro dan pemusnahan arsip.

2. Metode penilaian makro menentukan lokasi struktural di mana fungsi, subfungsi, dll dalam penilaian dapat berlangsung

3. Metode penilaian makro dilakukan untuk memahami sifat, fungsi atau program kearsipan

4. Metode penilaian makro membentuk hipotesis tentang di mana arsip berada

5. Metode penilaian makro menguji atau mengkonfirmasi hipotesis dengan menilai secara fungsional jenis arsip dalam program fungsional yang dinilai.

State Records of South Australia dalam Lolytasari menyatakan bahwa penilaian makro arsip merupakan sebuah pendekatan baru yang dapat merekomendasikan periode retensi arsip, dengan memperhatikan hal-hal berikut (Lolytasari, 2019):

1. Menentukan apa yang sudah dilakukan unit dan apa yang dilakukan staf.

2. Menganalisa dan mengklasifikasi fungsi dan aktivitas unit.

3. Mengidentifikasi hubungan antara fungsi dan aktivitas serta transaksi yang dibuat fungsi.

4. Mengidentifikasi kebutuhan stakeholder dan pengguna arsip.

5. Menentukan faktor resiko arsip yang disimpan dan dimusnahkan

6. Mengidentifikasi perundang-undangan, hukum, standar dan akuntabilitas

Banyak arsiparis lain menerapkan metodologi penilaian makro namun kebanyakan melakukan modifikasi dalam penerapan yang sebenarnya. Singkatnya, sebagian kecil arsiparis arsip publik telah secara sadar dan berhasil menerapkan pendekatan ini secara teoritis konsisten. Terlepas dari hasil untuk saat ini, karakter implementasi penilaian makro menimbulkan pertanyaan apakah teori penilaian makro dengan sendirinya merupakan dasar yang kuat untuk standardisasi. Dan meskipun efisiensi operasional dan penghematan biaya sulit ditentukan, Arsip Nasional menggunakan sumber daya yang sama untuk mencapai hasil ini. Namun, dalam ambiguitas yang muncul antara teori dan praktik di Arsip Nasional dari penerapan metodologi ini. Dengan demikian penilaian makro dapat memberikan dasar yang sangat baik untuk menstandarisasi kriteria dan metodologi penilaian (Beaven, 1999)

\section{Implementasi Penilaian Makro Arsip Dalam Organisasi}

Lolytasari (2019) melakukan penelitian yang berjudul Penilaian arsip makro di fakultas ilmu tarbiyah dan keguruan (FITK) UIN Syarif HIdayatullah Jakarta. Penelitian ini menganalisis penilaian makro arsip di Fakultas Tarbiyah dan Ilmu Keguruan (FITK) UIN Syarif Hidayatullah Jakarta. Aspek analisis yang dilakukan adalah kegiatan penilaian makro arsip di FITK UIN Syarif Hidayatullah Jakarta dan identifikasi kriteria penilaian arsip berdasarkan struktur organisasi. Penelitian ini merupakan penelitian penilaian makro kualitatif melalui observasi fungsi bisnis. Pengumpulan data dilakukan dengan observasi, kuisioner dan wawancara. Hasil penelitian menunjukkan bahwa penilaian makro arsip dilakukan secara parsial di setiap unit kerja. Hal itu terjadi karena tidak adanya pedoman penilaian makro arsip. Pelaksanaan penilaian makro arsip sebagai standar penilaian arsip dan dasar pembuatan jadwal arsip didasarkan 
pada pengalaman dan keahlian seorang pengelola arsip. Penilaian arsip juga tidak mengacu pada pedoman ANRI.

Putra \& Mirmani (2018) melakukan penelitian yang berjudul Analisis Fungsional pada Penilaian Makro Rekod di Perusahaan MRO: GMF AeroAsia. Penelitian ini menganalisis kebutuhan fungsional dalam penilaian arsip di perusahaan MRO (Maintenance, Repair \& Overhaul) pesawat terbang di PT GMF AeroAsia. Dalam penelitian ini dikaji beberapa aspek yakni proses dan komponen analisis fungsional dalam metode penilaian makro arsip yang dipengaruhi oleh karakter lingkungan bisnis dan industri perusahaan. Hasil penelitian mengungkapkan bahwa proses analisis fungsional dalam menilai arsip dalam perusahaan PT GMF AeroAsia secara parsial sesuai kebutuhan perusahaan. Proses penilaian arsip dilakukan dengan mengikuti karakter industri MRO yang terdiri dari rentang unit kerja yang luas, keberadaan peraturan otoritas penerbangan yang berbeda-beda pada setiap unit serta pengawasan yang ketat terhadap pemenuhan peraturan-peraturan tersebut. Salah satu komponen mengenai peraturan otoritas penerbangan adalah perihal masa simpan dan kegunaan dokumentasi dari kegiatan yang dilakukan suatu unit, maka dari itu dalam melakukan penilaian, arsiparis perusahaan akan bekerja sama dengan setiap unit untuk menilai masa simpan arsip berdasarkan pengalaman dan pemahaman mereka terhadap pemenuhan peraturan otoritas penerbangan.

\section{KESIMPULAN}

Penilaian arsip merupakan sebuah tindakan penting dan strategis dalam manajemen arsip untuk menentukan informasi yang bernilai bagi sebuah organisasi. Penilaian terhadap arsip sendiri dilaksanakan dalam rangka penyusunan Jadwal Retensi Arsip (JRA) juga untuk kepentingan dalam melakukan penyusutan arsip. Secara umum, dalam Undang-undang, Peraturan Pemerintah, Peraturan Kepala ANRI maupun Surat Edaran Kepala ANRI tidak menjelaskan secara langsung mengenai penilaian arsip, namun dalam UU, PP, PERKA maupun SE tersebut dapat disimpulkan bahwa penilaian merupakan bagian dari keharusan yang wajib dikalkukan sebelum pelaksanaan penyusutan arsip maupun dalam rangka penyusunan Jadwal Retensi Arsip.

Penilaian makro merupakan sebuah pendekatan untuk penilaian arsip dan membahas mengenai teknik penilaian dan penilaian makro pada tingkat teoritis yang tujuan utamanya bukan wacana teoritis tetapi lebih ke eksplorasi metodologi. Penilaian makro merupakan penilaian yang bersifat top-down dimana arsiparis atau pengelola arsip tidak lagi menilai arsip sebagai sebuah akhir dari proses kegiatan organisasi atau bottom-up. Penilaian top-down dalam penilaian arsip sudah ditentukan sejak awal sebuah arsip diciptakan.

Metodologi penilaian makro adalah cara di mana definisi teoretis atau filosofis dari nilai dapat diidentifikasi dan diterapkan dalam realitas kerja. Dalam implementasinya, arsiparis banyak yang menerapkan metodologi penilaian makro namun kebanyakan melakukan modifikasi dalam penerapan yang sebenarnya. Singkatnya, sebagian kecil arsiparis arsip publik telah secara sadar dan berhasil menerapkan pendekatan ini secara teoritis konsisten. Terlepas dari hasil untuk saat ini, karakter implementasi penilaian makro menimbulkan pertanyaan apakah teori penilaian makro dengan sendirinya merupakan dasar yang kuat untuk standardisasi. 


\section{DAFTAR PUSTAKA}

Beaven, B. P. N. (1999). Macro-Appraisal : From Theory to Practice * Introduction : Macro-Appraisal as a Candidate for a Standard of Archi- val Appraisal. Archivaria, 48, 154-198.

Cook, T. (2004). Macro-appraisal and Functional Analysis: Documenting governance rather than government. Journal of the Society of Archivists, 25(1), 5-18. https:// doi.org/10.1080/0037981042000199106

Cook, T. (2005). Macroappraisal in theory and practice: Origins, characteristics, and implementation in Canada, 1950-2000. Archival Science, 5(2-4), 101-161. https://doi.org/10.1007/s10502-005-9010-2

Duranti, L., \& Franks, P. C. (2015). Encyclopedia of archival science. Rowman \& Littlefield.

Effendhie, M. (2019). Arsip, Memori, dan Warisan Budaya. In Publikasi dan Pameran Arsip.

International Council on Archives, C. on E. R. (1997). Guide for managing electronic records from an archival perspective. International Council on Archives.

Lolytasari, M. (2019). Penilaian arsip makro di fakultas ilmu tarbiyah dan keguruan (FITK) UIN Syarif HIdayatullah Jakarta. Jurnal Kearsipan ANRI, 8(1), 178-251.

Melfianora. (2019). Penulisan Karya Tulis Ilmiah dengan Studi Literatur. Open Science Framework, 1-3. osf.io/efmc2

Peraturan Kepala ANRI (PERKA ANRI) No. 37 Tahun 2016 tentang Pedoman Penyusutan Kearsipan.

Peraturan Kepala ANRI (PERKA ANRI) No. 47 Tahun 2015 tentang Jadwal Retensi Arsip

Peraturan Pemerintah No. 34 tahun 1979 tentang Penyusutan Arsip

Putra, A. P., \& Mirmani, A. (2018). Analisis Fungsional pada Penilaian Makro Rekod di Perusahaan MRO: GMF AeroAsia. Proceeding INUSHARTS (International Young Scholars Symposium, 2, $7^{3} 6$.

Sasmita, N., \& Sutirman, S. (2017). Study on Implementation of Electronic Records Management System in Yogyakarta City Government Office. Public Policy and Administration Research, May.

Schwartz, J. M., \& Cook, T. (2002). Archives, records, and power: The making of modern memory. Archival Science, 2(1-2), 1-19.

Surat Edaran Kepala ANRI Indonesia Nomor: SE/02/1983 Tanggal 16 Mei 1983 tentang Pedoman Umum untuk Menentukan Nilai Guna Arsip.

Undang-Undang No. 43 Tahun 2009 Tentang Kearsipan 